\title{
De sociale kwestie; honderd jaar later
}

Citation for published version (APA):

Geers, A. J. C. M. (1990). De sociale kwestie; honderd jaar later. Kluwer. https://doi.org/10.26481/spe.19901116ag

Document status and date:

Published: 16/11/1990

DOI:

10.26481/spe.19901116ag

Document Version:

Publisher's PDF, also known as Version of record

\section{Please check the document version of this publication:}

- A submitted manuscript is the version of the article upon submission and before peer-review. There can be important differences between the submitted version and the official published version of record.

People interested in the research are advised to contact the author for the final version of the publication, or visit the DOI to the publisher's website.

- The final author version and the galley proof are versions of the publication after peer review.

- The final published version features the final layout of the paper including the volume, issue and page numbers.

Link to publication

\footnotetext{
General rights rights.

- You may freely distribute the URL identifying the publication in the public portal. please follow below link for the End User Agreement:

www.umlib.nl/taverne-license

Take down policy

If you believe that this document breaches copyright please contact us at:

repository@maastrichtuniversity.nl

providing details and we will investigate your claim.
}

Copyright and moral rights for the publications made accessible in the public portal are retained by the authors and/or other copyright owners and it is a condition of accessing publications that users recognise and abide by the legal requirements associated with these

- Users may download and print one copy of any publication from the public portal for the purpose of private study or research.

- You may not further distribute the material or use it for any profit-making activity or commercial gain

If the publication is distributed under the terms of Article $25 \mathrm{fa}$ of the Dutch Copyright Act, indicated by the "Taverne" license above, 
De sociale kwestie; honderd jaar later 


\section{De sociale kwestie; honderd jaar later}

\section{REDE}

uitgesproken bij de aanvaarding van het ambe van gewoon hoogleraar in het recht, in het bijzonder het sociaal recht aan de Rijksuniversiteit Limburg,

op vrijdag 16 november 1990

door

mr. A.J.C.M. Geers 
ISBN 9031206946

(C) I990, Uitgeverij Kluwer bv, Deventer 
Mijnheer de Rector Magnificus,

Zeer gewardeerde toehoorders,

\section{Twee andere redes}

Op 3 september wan dit jar opende minister-president Lubbers het academisch jaar van de Katholieke Universiteit van Nijmegen. ' Naast een antal andere, de aandacht trekkende opmerkingen, $k$ wam de heer Lubbers als de nationale geneesheer-directeur tot de volgende diagnose van de patiënt Nederland: "Als men de statistieken van arbeidsongeschik theid, ziekteverzuim, drop-outs en daaraan gerelateerde werkloosheid in ons land bestudeert, moet men erkennen dat ons land ziek is. Daarom moeten wij niet minder dan het honderd jaar geleden gebeurde opnieuw spreken wan een sociale kwestie; "en tegelijk moeten wij niet minder dan honderd jaar geleden vaststellen dat de politiek dit probleem niet alleen aankan.' Vervolgens stelde hij vast dat de aanpak van het probleem in feite plaatsvindt in het geheel van de samenleving en niet beperkt wordt tot het domein van de overheid. In dit verband wees hij op het fenomeen van zelfregulering. Ten aanzien van dit laatste punt moet ik er echter onmiddellijk op wijzen dat de historische parallel met honderd jaar geledlen die de heer Lubbers trok niet klopt: tòen werd umamers juist gepleit vóór ingrijpen door de overheid tegen de feitelijke zelfregulering in de ondernemingen, lees: de eigenaren/werkgevers.

Interessanter is het antwoord op de vraag hoe het nu komt dat de statistieken tot de conclusie leiden dat het land ziek is - ondanks of dankzij bijna tien jaar bewind van heelmeester Lubbers? Een duidelijk antwoord op deze vraag geefi de heer Lubbers in Nijmegen niet. Maar gelukkig werd op diezelfde dag elders in het land het Sociaal-Cultureel Rapport van het Social an Cultureel Planbureau aangeboden aan minister d'Ancona van wwC. ${ }^{2}$ Ook dit rapport constateert dat het groeiend aantal arbeidsongeschikten voor de Nederlandse samenleving een steeds zwaarder probleem vormt. Gevreesd moet zelfs worden dat

1. De openingsrede is afgedrukt in Stcrt. 1990,171 .

2. Social cn Cultured Panburead, Social con Cultureel Rapport 19yo, Rijwijk/Den Hatag 1900 . 
in de loop van de jaren negentig de grens van één miljoen arbeidsongeschikten wordt overschreden. Het rapport doet ook een poging om opgrond wan diverse onderzoken de oorzaken van deze ontwikkeling te kenschersen. ${ }^{3}$

In de ecrste plats wordt ruim $44 \%$ van de volumegroei toegerekend an de groei van de beroepsbevolking en de invoering van de AAw.

Een tweede verklaring vindt het rapport in een verruming van het ziek tebegrip in de samenleving. Klachten worden eerder onderkend, en als ziekte geaccepteerd. Psychische ziekten vormen in dit verband de belangrijkste groeicategorie: in 1970 was dat voor éen op de acht personen de reden van instroom, in 1988 woor één op de drie uitkeringsgerechtigden. De diagnose psychische stoornissen zou aldus ongeveer een zesde wan de volumegroei kunnen verklaren.

Een volgend deel van de groei wordt verklaard door een verandering in de arbeidsomstandigheden. Met name de psychische belasting van de werkneriners wordt steeds $z$ waarder door een toenemende complexiteit van de arbeid. De introductie van nieuwe technologieën en meer hexibele vormen van arbeidsorganisatie stellen hoge eisen aan technische en sociale vaardigheden; door reorganisaties, samenvoegingen en dergelijke is de onzekerheid over de eigen positie in het bedrijf toegenomen en bovendien de tijdsdruk van werkenden steeds groter doordat meer taken verdeeld worden. Dit geldt in het bijzonder voor jonge vrouwen die betaalde arbeid combineren met huishoudelijke taken. De toegenomen psychische belasting van werknemers blijkt ook wit ander recent onderzoek naar het voorkomen wan stress onder werknemers. Hieruit blijkt dat $54 \%$ van de werknemers het werk geestelijk inspannend vindt, $29 \%$ vindt het werk vaak te vermoeiend, $38 \%$ ergert zich vaak an anderen, $44 \%$ voelt zich ondergewardeerd en $39 \%$ ziet te weing vooruitzichten. "Tenslotte weet ook de nota Sociale Zekerheid 1991 te melden dat in 30,5\% de oorzaak wan arbeidsongeschiktheid ligt in psychische klachten.

De latste verklaring in het Social-Cultureel Rapport is een verslechtering van de concurrentiepositie van gehandicapten op de arbeidsmarkt, met name onder druk wan de werkloosheid onder bepaalde groepen.

Terug in de tijd en weer naar Nijmegen. In 1974 hield daar een andere

3. Rapport ta.p. p. $121-127$.

4. M.A.J. Kompier, F.H.G. Marcelisen, Handboek werkstress, Amsterdam 19go, p. I4. 
minister-president een - eveneens geruchtmakende - rede. Het was de socialist Den Uyl die sprak voor een gehoor van christelijke werkgevers. ${ }^{5}$ En het is opvallend om te moeten constateren dat, nadat hij, kennelijk zonder ironie, de ondernemers beklaagde ondat 'vandaag de dag niemand hun dankbaar schijnt te zijn' tot een zelfde conclusie komt alls zestien jaar later zijn christen-democratische opvolger en vele onderzoeksrapporten. Ik citeer Den Uyl: "Veel werknemers in het industricle arbeidsproces voelen zich evenmin gelukkig. De omstandigheden waaronder zij werken, de monotonie van het werk van velen die meer zouden kunnen, het gevoel machteloos te zijn in dat grote raderwerk, leidt in veel gevallen tot negatieve reacties voor de onderneming, de werknemers zelf, uiteindelijk voor de matschappij als geheel. Er is tegen deze achtergrond een vlucht van mensen in het ziekteverzuim, in arbeidsongeschiktheid, in het niet aanvaarden van arbeidsplaatsen door werkzoekenden." Vervolgens concludeert Den Uyl tot de noodzaak van bezinning op de structuur van de onderneming. Ik citeer hem nog énmaal: "In de huidige economische orde staan werkgever en werknemer nog altijd tegenover elkaar. De één geeft. De ander kan nemen. Maar u weet zeker dat het zaliger is te geven dan te ontvangen. Mij gaat het om een structurur waarin die tegenstelling is opgeheven."

\section{Sociaal-rechtelijke activiteiten}

Het opheffen van tegenstellingen: is dat niet ook de belangrijkste doelstelling van het sociaal recht? De vraag stellen is haar-positief - beantwoorden. Het is niet mijn bedoeling om hier uitvoerig in te gaan op inhoud, functies, kenmerken en karakteristieken van het sociaal recht. ${ }^{.}$In elk geval bestaater naar mijn smaak overeenstem ming over de belangrijkste doelstelling wan het social recht: reitelijke ongelijk-

5. J.M. den Uyl, Socialisme en vrije ondernemingegewijze produktic, Rede voor het NCW op If oktober 1974 te Nimegen, in: Inzicht en utucht, Amsterdam 1978, p. $18 \div-195$

6. I.M. den Uyl ta.p., p. 194.

7. J.M. den Uyl ta.p., p. 195.

8. Herover bjyoorbeld A.Ph.C.M. Jaspers, G.J.]. Heerma van Vos, De uitelagingen van het sociall recht, sn 1986 , p. A 
heid, feitelijke tegenstellinger, namelijk die tussen werkgever en werknemer, tussen de sterkere en de zwakkere, juridisch compenseren door het geven van bescherming en het bieden van ontplooiingsmogelijkheden aan de $z$ wakkere partij. Hierwoor noemde ik een aantal - niet door mij bedachte - oorzaken voor het grote aantal mensen dat door arbeidsongeschiktheid buiten het arbeidsproces staat. Het gaat hierbij dus om het probleem dat grote groepen mensen niet binnen boord, binnen de onderneming worden, of kunnen worden, gehouden. Daarnast, mar ermee samenhangend, bestat een ander probleem: hoe komen grote - valk weer andere - groepen er weer in?

Met name het eerste probleem zou voor het sociaal recht een belangrijke uitdaging moeten wormen." Naast de nauwelijks beheersbare oorzaken van toeneming van het aantal arbeidsongeschikten zoals de groei van de beroepsbevolking en de invoering wan de AAw zijn er ook beinwloedbare oorzaken zoals de psychische belasting van groepen werknemers. Zal de psychische belasting niet minder zijn naarmate werknemers zich veilig, beschermd weten met name door behoorlijke arbeidsomstandigheden en naarmate zij meer ontplooiingsmogelijkheden hebberi door zeggenschap, door uitings- en actiemogelijkheden? Kennelijk is het sociaal recht er, ondanks zijn doelstelling, ondanks zijn pretenties nog niet in geslaagd om dit in voldoende mate te bieden.

Hoe komt dat nu? Wat is er eigenlijk wèl gebeurd? Wat mag of moet er in de toekomst verwacht worden, en vooral ook van wie? Om vast een gedeeltelijk antwoord op de laatste vraag te geven: de beoefenaar wan het social recht kan het zich nat mijn mening in elk geval niet veroorloven om alleen vanaf de zijlijn commentaar te leveren in de worm van abstracte bespiegelingen of juridische hoogstandjes in concrete gevallen. Natuurlijk is dat onmiskenbaar uiterst belangrijk, maar tegélijkertijd en zonder elkaar uit te sluiten is politieke en matschappelijke actie nodig, is positie kiezen nodig, telkens als geconstateerd wordt dat het sociaal recht tekort schiet en in het besef dat het recht van morgen mede gevormd wordt door de politiek van vandag. ${ }^{10} \mathrm{Ik}$ zal ook, hoewel dergelijke mededelingen meestal aan het cinde van een rede als deze worden gedaan, wanuit dit besef trachten inhoud te geven aan mijn leeropdracht.

Om de overige vragen te beantwoorden wil ik een aantal social-

9. Vgl. A.T.J.M. Jacobs, De ondermining wan het social recht, sh 1989, p. 36-39. 10. T. Hookenboom, Machr, social techt en rechtelike legitimatie, sR $\llbracket 989$, p. 4r. 
rechtelijke onderwerpen belichten die in de periode tussen het verhal van de heer Den Uyl en dat van de heer Lubbers een rol hebben gespeeld en nog spelen. Hoewel onderling verschillend in inhoud, vormgeving en adressant hebben zij alle gemeen dat zij invulling kumnen geven aan de beschermings- en ontplooingsfunctie van het sociaal recht - en daarmee aan de preventieve functie ten aanzien van arbeidsongeschiktheid met name vanwege psychische oorzaken. Het gaat om:

I. welzijnsbeleid in de onderneming;

2. klachtrecht in de onderneming;

3. vakbondswerk in de onderneming;

4. positie van gewetensbezwaarden in de onderneming;

5. seksuele intimidatie in de onderneming;

6. positie van werknemers in deeltijd;

\subsection{Het welzinsbeletd in de onderneming}

In $1980 \mathrm{trad}$, na een parlementaire behandeling van drie jaar, de eerste fase van de Arbowet in werking. Sinds die tijd is de arbeidsongeschiktheid schrikbarend gegroeid. Dat is natuurlijk wat gek als de doelstelling van de wet goede arbeidsomstandigheden, welzijn in verband met arbeid is en het ontbreken daarvan een belangrijke oorzaak van arbeidsongeschik theid. Twee oorzaken voor deze (ogenschijnlijke?) discrepantie wil ik aangeven. In de eerste plats heeft onderzoek, zowel in de particuliere sector als bij de overheid, grof samengevat, aangetoond dat werkgevers, werknemers, deskundigen en Arbeidsinspectie er onvoldoende in zijn geslaagd om daadwerkelijk inhoud te geven aan de in werking getreden bepalingen van de Arbowet. Met name de onderlinge samenwerking van de actoren laat nog veel te wensen over." In de tweede plaats - naar mijn smaak belangrijker - zijn de meeste bepalingen die een principiële vernicuwing betekenen ten opzichte van de wroegere wetgeving pas per 1 oktober jl. in werking getreden. Ik doel hierbij op de zogenaamde welzijnsbepalingen in art. 3 en art. I 7 en op de verplichting om een jaarplan te hebben over de veiligheid, de gezond-

11. I.T.S., De Arbowet in twitwoering, Een onderzock naterwaringen in de praktijk, Den Haag 2988; I.T.S., Overheid en Arbowet, Een onderzock natrervarngen in de praktik, Den Haag 1989. 
heid en het welzijn in de onderneming en daarover vooraf overleg te voeren met de werknemers in art. 4 .

Hoewel het begrip welzijn beperkt wordt tot de inhoud en de organisatie van het werk is het voor het welbevinden van de individuele werknemer van groot belang. Het gaat immers om de volgende vier verplichtingen van de werkgever.

In de eerste plaats moet het ergonomische principe worden gehanteerd dat het werk moet worden aangepast aan de mogelijkheden van de werknemer. Met mogelijkheden wordt gedoeld op persoonlijke eigenschappen van de werknemer met betrekking tot leeftijd, geslacht, lichamelijke en geestelijke gesteldheid, ervaring, vakmanschap en kennis van de voertaal. Zonodig moet speciaal toezicht worden uitgeoe-

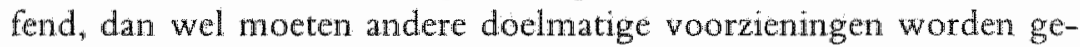
troffen. Met name voor bepaalde groepen werknemers zoals ouderen, wrouwen, gehandicapten, buttenlandse werknemers, kan deze bepaling wan grote praktische betekenis zijn. In de tweede plats moet er zoveel handelingsvrijheid zijn voor de werknemer dat hij het werk naar eigen inzicht kan verrichten. In de derde plaats moet de werknemer sociale en functionele contacten kunnen hebben met collega's. In de vierde plaats dient de werknemer zicht te kunnen hebben op doel, resultaten en eisen die met het werk samenhangen.

Art. I7 gaat over de organisatorische vormgeving van het welzijnsbeleid. Het artikel geeft aan welke taken in dat kader verricht moeten worden, bijvoorbeeld het doen van aanbevelingen over het te voeren welzijnsbeleid in de onderneming, maar niet door wie. Het artikel geldt alleen voor bedrijven waarin 5 oo of meer werknemers in dienst zijn. Tot slot moet het arbeidsomstandighedenbeleid neergelegd worden in een schriftelijk plan. Deze werplichting geldt alleen voor bedrijven thet 100 of meer werknemers. ${ }^{12}$ Over dit plan dient vooraf overleg gevoerd te worden met de or, de Arbocommissie of bij het ontbreken daarvan met de belanghebbende werknemers.

Het is met name door de felle tegenstand van de werkgevers in de

13. De formulering woor de getalscriteria in de betreffende AMYB"s luidt: "... in dienst wan de werkgever..." Volgens de toelichtingen is de bedoeling van deze formulering dat het witwitend gat om werkmemers in de zin van are. 637 a BW of zij die op publickrehtelijke anstelling werkatam zijn. Naar mijn mening is dit echter onjust, ondat in de Arbowet, was de AMvB's op zijn gebasserd, het begrip werknemer "in het bij of krachtens deze wet bepaldde" ook omwat ingeleende werknemers, uitzendkrachten, stagiaires en leerlingen. 
Arboraad - daarin gevolgd door opeenvolgende kabinetten - dat de volledige Arbowet vijftien jaar na de adviesaanvraag aan de skr door het kabinet Den Uyl, tien jaar na haar verschijning in het Staatsblad en zeven jaar na de inwerkingtreding van de zogenaamde eerste fase eindelijk per $\mathbb{I}$ oktober 1990 in werking is getreden. ${ }^{13}$ In dit verband wil ik erop wijzen dat werkgevers en de diverse dereguleringscommissies zich juist tegen het welzijnsaspect in de wet het meest hebben verzet. Het is nu de vraag hoe in de ondernemingen gestalte zal worden gegeven aan deze welzijnsbepalingen. In elk geval hebben voorgem. schiedenis en implementatie van de wet tot nu toe ertoe geleid dat de overheid via de Arbeidsinspectie actiever gaat optreden dan oorspronkelijk in de bedoeling lag. Bevordering van de zelfwerkzaamheid, waar naar gebleken is onvoldoende op vertrouwd kan worden, wordt omgebogen naar actieve beïvloeding." Met name voor het concreet vormgeven aan het welzijn in de onderneming kan deze ombuiging van bellang zijn.

\subsection{Klachtrech in de onderneming}

In 1967 nam de IAO een Aanbeveling a an over het onderzoek van klachten in de onderneming met de bedoeling daarvoor een oplossing te vinden. ${ }^{15}$ De Aanbeveling liet het aan de lidstaten over op welke wijze er uitvoering aan zou worden gegeven zodat wetgeving nict hoefde. Toch werd al in de nota bij de toezending van de Aanbeveling aan de Staten-Generaal in 1972 het standpunt ingenomen dat ook in ons land een vorm van wettelijke regeling van het klachtrecht voor individuele werknemers tot stand zou komen. ${ }^{16}$ Extra munitie voor cen regeling terzake werd in 1975 geleverd toen de resultaten van een onderzoek bekend werden waaruit bleek dat een groot aantal werknemers klaagde over de arbeidsomstandigheden waronder gewerkt moest worden (met name warmte, stof, lawaai), over gebrek aan perspectieven in de onderneming, over het functioneren van medezeggenschap en over het

r. Oxer de inwerkingredingsperikelen: A.J.C.M. Gecrs, Recht en humanisering van de arbeid, Deventer 1.988. p. $89-97$ en p. 10s-rin.

14. Onlangs minister De Vries tijders cen uirgebreide commissievergadering op 16 mei $1990,00 \%, 34$.

15. Aanbeweling nr. 130, Tractatenblad 1960 , nr. 174.

16. TK $1971-1972,11935$. 
ontbreken van mogelijkheden tot Klagen. ${ }^{37}$ Zowel de Aanbeveling als de resultaten van het genoemde onderzoek leidden in 1977 tot een adviesaanvraag aan de sen. Het advies verscheen in $1981 .^{18} \mathrm{Na}$ de constatering van de ser, onder meer, dat de bestaande juridische regelingen onvoldoende zijn on tegemoet te komen aan de behoefte van de individucle werknemer 'aan beveiliging tegen gebeurtenissen en omstandigheden die zijn persoonlijke positie als werknemer ongunstig beinvloeden, en aan de middelen om daartegen op te komen' en dat het klachtrecht cen bijdrage kan leveren 'aan een goede tenuitvoerlegging van de arbeidsovereenkomst en tot een normering van de gezagsuitoefening door de werkgever' bepleit hij in de eerste plats een wettelijk erkend recht voor iedere werknemer om te klagen zonder dat hij om dic reden in zijn positie zou kunnen worden benadeeld. In de tweede plaats zou op een schriftelijk ingediende klacht een schriftelijke en gemotiveerde beslissing moeten komen van de werkgever. In de derde plaats zou de werknemer zich moeten kunnen laten bijstaan door een collegawerknemer. Het recht om zich op de rechter te beroepen zou behouden blijven.

Hoewel de ser eveneens unaniem overtuigd was wan het nut van klachtenreglementen pleitte een minderheid (de CNV-leden en een aantal Kroonleden) voor een wettelijke opdracht aan de werkgever om $z o^{\prime}$ reglement vast te stellen, althans voor ondernemingen waarin krachtens de wor een or werkzaam is. Hierin zou geregeld moeten worden de wijze van klagen, de klachtenopvang, de klachtenbegeleiding, de klachteninstantie bij beroepsprocedures, het informatierecht en de geheimhouding. De meerderheid bepleitte in dit opzicht vrijblijvendheid. Reglementen kùmnen door de werkgever worden vastgesteld, maar het moet niet verplicht worden. Als de werkgever dit owerigens doet heeft hij instemming nodig van de or op basis van art. 27 lid I van de wor, tenzij in deze kwestic inhoudelijk is voorzien door de van toepassing zijnde cao.

In 1986 wordt het voorstel van wet net $\mathrm{Mv} T$, inhoudende en sobere en beperkte regeling, aan de Raad van State gestuurd. Deze adviseert

17. Stichting Wetenschapelijk Onderzoek Vakentrales en Institut voor Toegepaste Sociologic, Ontrede cn klachten van werknemers, een studie naar het ontstadn, de opvang en de oplosing van klachten wan werknemers ten behoeve van het beleid. Utrechu/Nijnogen, 1975 .

18. Stk, Advies inzake let klachtrecht van individuete werknemers, Den Hag, $198 \mathrm{r}$, nr. 14. De advicsanvrag is als bijage opgenomen. 
het jaar daarop, in beginsel positief. De regering arzelt echter of wetgeving nu wel geindiceerd is en vraagt deze kecr advies aan de Commissic woor de toetsing van wetgevingsprojecten. De commissic werd gevraagd het belang van de inhoudelijke aspecten van het voorstel af te wegen ten opzichte van het streven nar deregulering. Op basis hiervan wordt uiteindelijk een nieuw wetsvoorstel voorgelegd aan de Raad van State. Deze adviseert tot indiening maar de minster van Sociale Zaken en Werkgelegenheid will liever nog het overleg afwachten in de Stichting van de Arbeid.

In januari 1990 beveelt de Stichting an dat de werkgever cen klachtenregeling opstelt en dat partijen bij de cao de totstandkoming ervan bevorderen. Suggesties worden gedaan voor de vormgeving van de regelingen. Geen woord echter over de noodzak van een wettelijke opdracht. Uiteindelijk, achttien jaar na de regeringsmededeling dat een wettelijke regeling gewenst zou zijn, wordt op 17 april van dit jaar ingediend het wetsvoorstel tot "wijziging van thet Burgerlijk Wetboek in verband met de invoering van een klachtrecht van de individuele werknemer'. "Het voorstel is uiterst sober, sluit aan bij het ser-advies en krijgt een plaats als nieuw artikel ( $1638 \mathrm{pp}$ ) in het $\mathrm{BW}$. Volstaan wordt met een expliciete erkenning van het klachtrecht, het recht op een gemotiveerd antwoord, het recht op bijstand van een derde en een werbod tot benadeling van de indiener van de klacht en van degene die hem bijstand heeft verleend. Het voorstel bevat geen verdere procedurele voorschriften, noch een wettelijke opdracht tot het opstellen van een klachtenregeling. ${ }^{20}$ Dit wordt overgelaten aan de sociale partners. Het recht geldt slechts voor diegenen die volgens de arbeidsovereenkomst in de zin van het Bw werkzaam zijn.

Het voorstel is teleurstellend. Zolang de werkgever op het punt van instellen, inhoud en uitwoering van een klachtenregeling tot niets verplicht wordt ben ik bang dat deze vrijblijvendheid ertoe leidt dat vooral in die ondernemingen war een klachtenreglement het meest nodig is, niets zal gebeuren. Dit standpunt wordt ook bevestigd door een onderzoek naar het functioneren van bestaande klachtenregelingen. Ik citeer

19. TK $1980-1990,21514$, nrs. $1-3$.

20. Eveneens woor ecn sobere regelgewing op dit punt: H.L. Bakels, Het individurel klachredt, de goede wetkgever en het collectiel overleg, SMA 1981, p. 302; F. Koning, Het selladvies inzake het klachtrecht wan individuele werknemers, $\$ M A$ t98r, p. 8.4. P.F. van der Heijden, Een eerlijk proces in het social recht?, Deventer $1989, \mathrm{p} .151$. 
uit de conclusie: 'Gegeven de ervaringen met het functioneren van al bestaande klachtenregelingen mag men van het effect van een dergelijke wet op het gebruik van de geboden mogelijkheden niet al te veel werwachten, als ển en ander niet in een goed doordachte klachtenregeling wordt uitgewerkt. Daarbij moet rekening gehouden worden met bedrijfseigenschappen, die een negatieve invloed kumen uitoefenen op het gebruik van de regeling'. "Dus wel een opdracht tot regelgeving in de ondememing mar tevens rumte latend voor de verschillen tussen de ondernemingen onderling ${ }^{2 x}$ Het wetsvoorstel geldt niet voor ambtenaren en de groepen werknemers die niet volgens arbeidsovereenkomst naar burgerlijk recht in de onderneming werkzaam zijn zoals stagiaires, uitzendkrachten, leerlingen. Volgens de MvT zijn er voor ambtenaren al mogelijkheden en woor zover deze niet toereikend blijken zou alsnog een voorziening kunnen worden getroffen. Wat betreft de restgroep acht de MvT "het niet passend in het kader van dit wetsvoorstel voor een groep werknemers die in de regel rechten voortvloeiend uit de arbeidsovereenkomst ontbeert - een aparte wettelijke voorziening te treffen ${ }^{2}{ }^{3}$ De argumenten zijn niet sterk. De laatstgenoemde groep zou nu juist wel eens het meest profijt kunnen hebben van een effectief functionerend klachtrecht en het ontbreken van eenzelfde regeling voor a mbtenaren is in strijd met het streven om ambtenaren en werknemers zoveel mogelijk gelijk te behandelen. Het vooruizzicht van een eventuele afzonderlijke regeling woor ambtenaren is, gezien de voorgeschiedenis van het thans voorliggende wetsontwerp, waarschijnlijk niet meer dan een luchtspiegeling aan de verre, verre einder.

In de MvT wordt gezegd dat een goede en doelmatig ingerichte klachtenregeling een methode kan zijn om gevoelens van onvrede zichtbaar te maken en om te komen tot een oplossing in der minne. Bovendien kan het als bijsturingsmechanisme functioneren voor de wijze warop de werkgever gebruik makt van zijn gezagsbevoegdheid. Klachtrecht zal de interne verhoudingen in de bedrijven ten goede komen en - bijkomend voordeel - de druk op externe of bijzondere procedures verminderen. ${ }^{24}$ En door Olbers werd onlangs nog be-

21. E.A. Mante-Mejier, J.J.G.J. vall Helvert, Indivdnee klachtrecht, Het str-advies getoctst aan de sociale werkelijkheid, SMA, $1982, P .120$.

a. E. A. Mante-Mejjer, Confficten in organisaties: individuele klackten wen hehandeling Rotterdan ro89.

3.3. MvT, t.a.p. p. 3.

皮. MvT, ta, p. p. 
argumenteerd dat het bijvoorbeeld ook zou kunnen leiden tot een zorgvuldiger besluitvormingsproces voorafgande aan het ontslag op staande voet. ${ }^{25}$

Bij deze belangen steekt de magerte van het voorstel schriel af, ook in het licht van de omvang en oorzaken van arbeidsongeschik theid.

\subsection{Het wakbondswerk in de ondemening}

In 1971 werd door de IAO een verdrag vastgesteld betreffende de bescherming van werknemersvertegen woordigers in de onderneming en de hun te verlenen faciliteiten. ${ }^{26}$ Een nadere uitwerking werd neergelegd in een Aanbeveling. ${ }^{27}$ In 1975 is het verdrag door de StatenGeneraal goedgekeurd. Voor Nederland waren de ideeèn uit deze regelingen niet nieuw. Vanaf einde jaren zestig was er namelijk al een groeiende aandacht woor de rol van de vakbeweging in de afzonderlijke bedrijven. Vanaf die tijd werden er ook in de cao afspraken gemaakt over het verlenen van bepaalde faciliteiten aan vakbondswertegenwoordigers door de werkgever. ${ }^{29}$ Terzake om advies gevragd meende de SER in 1977 dat zekere algemene voorzieningen over het vakbondswerk in de onderneming zouden moeten worden getroffen. Een meerderheid vond echter dat hiervoor geen wettelijke regeling nodig was. Een minderheid, bestaande uit de werknemersleden, meende van wel. Gezien het belang ervan zou de overheid de ontwikkeling van het vakbondswerk moeten begeleiden en stimuleren. In 198 I werd de minderheid in de SER gevolgd met de indiening varn cen wetsontwerp. ${ }^{30}$ Een belangrijk argument voor een wettelijke regeling was het toegenomen belang van de $k$ waliteit van de arbeid, net name van de participatie en ontplooingsmogelijkheden binnen de specifieke arbeidssituatie in afzonderlijke ondernemingen. Naast de medezeggenschap van de or zou een meer ondernemingsgewijze belangenbehartiging door de vakbonden een belangrijk aanvullend instrument vormen. ${ }^{31}$ Als voordeel

\footnotetext{
25. M.M. Obers, Klachtrecht tegen een opdracht wan de werkgever. SMA, 1990, p. 260.

26. IAO-verdrag, nr. I35. Tractatenblad 1971, nr. 307.

27. Aunbeveling nr. 443. Tractatenblad 1073, nt, 41.

28. Wet van 25 juni $1975,5 \mathrm{tb}$. $1975.48 \mathrm{r}$.

29. G.E. van Vher, Bedrijvenwerk als yom van belangentbehartiging. Alphen anden Rijn, 1979 .

30. TK 1480-1981, 16703. nirs. $1-3$

31. TK 1980-198x, 16703, nr. 3 (MvT), p. 6 .
} 
wan een wettelijke regeling werd onder meer genoemd dat de gewenste werkingssfeer en enkele basisbepalingen op envoudige wijze rechtstreeks geregeld zouden kunnen worden en voor iedere ondernemer bindende kracht zouden hebben. In het ontwerp wordt het vakbondswerk inhoudelijk niet geregeld, maar wordt een algemene basisvoorziening gecreêerd volgens welke iedere werkgever in beginsel verplicht wordt om faciliteiten ten behoeve van het vakbondswerk te verschaften. Over aard en omvang van de faciliteiten zou overleg moeten worden gepleegd tussen ondememer en vakbond. Een aantal faciliteiten werd echter verplicht zoals het verlenen van toegang aan vakbondsvertegen woordigers-niet-werknemers, de verspreiding van informatie en het ter beschikking stellen van publikatieruimten. De verplichting zou alleen gaan gelden ten opzichte van de vakbond die drie procent of meer, mar tenminste tien werknemers in de onderneming onder haar leden telt. Daarnaast worden regels gesteld ter bescherming van de vakbondswerker tegen benadeling en ontslag.

Het feit dat toch gekozen was voor een wettelijke regeling - een regeling waarvan overigens met de beste wil van de wereld toch niet gezegd kan worden dat hiermee de factor arbeid cen substantiële bedreiging ging vormen voor de factor kapital - ontlokte aan Koning de constatering in SMA "dat het toch boeiend blijfti om te zien hoe centrumrechtse kabinetten in dit land bij de nadering van de verkiezingen soms wetsontwerpen produceren die, blijkens hun eerste reacties, aan werknemerszijde met blijdschap en aan werkgeverszijde met afschuw worden ontvangen.... ${ }^{32}$

Maar inmiddels waren de verkiezingen voorbij en, met een korte onderbreking, bleef centrum-rechts aan de macht. Toch, of moet ik zeggen darom, werd in 1984 besloten om de MvA twee jaar op te schorten op advies van de deregulerings-commissic-Geelhoed. Belangrijk argument was dat het een zaak betrof van de sociale partners en dat de cao derlalve het arngewezen instrument was. En zowel de commissie Geelhoed als de toen verantwoordelijke minister waren in dit opzicht positief over het zelfregulerend wermogen van de sociale partners. ${ }^{3 .}$ Het vervolg moet een teleurstellende ervaring geweest zijn. In 1985 moest

32. Koning, Het wersontwerp vakbondswerk in de onderneming. Fen momentopname uit onze arbeidsvechoudingen, SMA 1981, p. 49.

33. TK $1984-1985,17931$, nr, 2, p. $178-180$. 
de minister constateren dat de Stichting van de Arbeid niet in staat was om overeenstemming te bereiken. De minister achtte dit weliswar inderdaad "teleurstellend" mar tevens liet hij de Stichting weten niet te zullen terugkomen op zijn besluit on eind 1986 te beslissen over de voortzetting van de parlementaire behandeling van het wetsontwerp. ${ }^{34}$ De jaren verstreken. In de MvT bij zijn begroting van 1988 wist de minister mee te delen, alsof er nieuws onder de zon was: 'Over faciliteiten en rechtsbescherming voor vakbondswerk in de onderneming wordt overleg gevoerd in de Stichting van de Arbeid. In verband daarmee heb ik mijn beslissing over de voortzerting van de behandeling van het wetsontwerp Vakbondswerk in de onderneming nog aangehouden" "Dat kon de minister mòg een paar jaartjes doen want pas op 3 januari van dit jaar verscheen de aanbeveling van de Stichting van de Arbeid. Ondernemers en ondememersorganisaties zouden medewerking door middel van faciliteiten ten behoeve van het vakbondswerk moeten verlenen, indien vakbonden daar in het arbeidswoorwaardenoverleg om vragen. Het verlenen wan faciliteiten veronderstelt echter het bestaan van normale verhoudingen. Bij het ontbreken daarvan, zo vervolgt de aanbeveling, bijvoorbeeld in geval van een ernstig conflict. kan de ondernemer zich het recht voorbehouden de faciliteitenregeling buiten werking te stellen. Bij onjuist gebruik ervan kan de ondememer 'deze bovendien schorsen, niet echter dan na overleg met de vakbond aan wie de faciliteiten zijn toegekend.

Vervolgens besloot de minister van Sociale Zaken en Werkgelegenheid uit een centrum-links kabinet bij brief van 20 augustus $j l$, an de Tweede Kamer, gelet op de armbevelingen van de Stichting van de Arbeid en gelhoord de mening van de Tweede Kamer, ${ }^{36}$ tien jaar na de indiening ervan, tot intrekking van het wetsvoorstel vakbondswerk in de onderneming. De rechtsbescherming van de wakbondswerkers in de onderneming zal nader aan de orde kminen komen bij de behandeling van het wetsvoorstel inzake herziening van het ontslagrecht. ${ }^{17}$

Geen wettelijke regeling dus, maar een aanbeveling van de Stichting van de Arbeid aan de ondernemer om voorzieningen te treffen, tenminste als de vakbonden daar om vagen, en dan nog alleen van

34. TK $1985-1986,19200$, hoof dstuk XV ar. 2 , p. 35-36.

35. TK $1987-1988,20200$, hoofdstuk $x /$ nar, $2, \mathrm{p} .17$.

30. Mondeling overleg 0 juni $1990, \mathrm{TK}, 74-4130$.

37. Tk 1900-1991, 21900 , hoofdstuk XV, nr. 2, p. 33 . 
toepassing bij harmonieuze verhoudingen - althans niet bij ernstige conficten. Deze laatste beperking vormt tevens een belangrijk argument vóo een wettelijke regelling. Volgens de aanbeveling immers zou, juist als de faciliteiten het hardst nodig zijn, de werkgewer er eenzijdig een eind an kunnen maken. ${ }^{38}$ Maar behalve dit en de in de MvT genoemde argumenten zijn er nog meer redenen om het afzien van een wettelijke opdracht, in relatie tot het belang van het onderwerp, te betreurem. Wettelijk gegarandeerde faciliteiten voor het vakbondswerk kunnen een extra stimulans en ondersteuning vormen bij het zogenaamde werknemersonderzoek bijvoorbeeld naar lichamelijk en geestelijk ziek makende factoren in de ondememing. Gebleken is inmiddels dat door werknemersonderzoek met name op het terrein van de arbeidsomstandigheden verbeteringen tot stand zijn gebracht. ${ }^{39}$ Deze faciliteiten kunnen bovendien van belang zijn bij het behartigen van de belangen van juist diegenen die een meer marginale rol in de onderneming vervullen zoals deeltijdwerkers, thuiswerkers, flexibele werkers. De zeggenschaps- en vakbondsvoorzieningen sluiten vaak maar ten dele an bij het arbeidspatroon van deze werknemers, veelal werkzaam in het kleinbedrijf. Tenslotte kan een wettelijke ondersteuning van het vakbondswerk in de onderneming van belang zijn in het kader van de hulpverlening door de vakbond aan met name de vakbondsleden van de or, terwijl in de Arbowet bij het ontbreken van een or de vakbond zelfs enkele plaatswervangende rechten zijn toegekend zoals het verzoek aan de Arbeidsinspectie om in te grijpen in het arbeidsomstandighedenbeleid in de onderneming.

De drie vakcentrales FNV, CNV en MFre stellen naar mijn smaak terecht. dat door het intrekken van het wetsvoorstel de naleving van verdrag 135 van de IAO onvoldoende gewartborgd is, zeker in ondernemingen waar geen or functioneert. Daarom hebben zij inmiddels besloten een klacht in te dienen bij de IAO wegens schending wan het verdrag.

38. Vgl ook mijn Ter Visie in sk $1990, \mathrm{p} .75$ en het commentaar darop met majin nawoord in ske 1990, p. 183-184.

30. W. Buttelaar, R. Wreeman, Wakbondswerk en kwaliteit wan de arbeid, voorbeelden van werkinemersonderzoek in de Nederlandse industrie, Nijmegen 1985 . 


\subsection{Gewetensbezwarden in de andermening}

De laatste tien à vijftien jaren is een groejende belangstelling te constateren voor het verschijnsel gewetensbezwaren in dienstbetrekking. Hiervan getuigen bijvoorbeeld het toegenomen antal cao-bepalingen en enkele rapporten zoals die van de FNV en CNW over dit onderwerp. ${ }^{* 3}$ Hoewel over de $\mathrm{k}$ wantiteit van het verschijnsel geen gegevens bekend zijn wordt in het algemeen wel een uitbreiding van het verschijnsel aangenomen onder meer in verband met nieuwe ethische vragen over het ondernemingshandelen. Het gaat bijvoorbeeld om het werken of meewerken aan munitietransporten, om het drukken of verspreiden wan bepaalde lectuur, om handel met regimes die mensenrechten schenden, om het werken in verband mer milieugevaarlijke stoffen."

Naar aanleiding van schriftelijke vragen zond de minister in 1986 een discussienota over gewetensbezwaren in dienstbetrekking aan de Tweede Kamer. ${ }^{42}$ Volgens de nota moest van een wettelijke regeling geen heil worden verwacht. Ook de Kamer vond dat de minister eerst maar cens met de Stichting van de Arbeid moest overleggen over een door de Stichting op te stellen gedragscode. Uit het verslag van de standpunten van de in de Stichting vertegenwoordigde organisaties bleek dat de meningen over dit onderwerp bij de socialle partners zeer uiteenliepen: werkgevers vonden wetgeving niet zinvol, de werknemerswertegenwoordigers achtten wetgeving (FNV) dan wel code of aanbeveling (CNV en MHP) noodzakelijk. ${ }^{43}$

Vervolgens concludeerde de Kamer dat een wettelijke regeling kennelijk onontkoombaar was, waarna de minister de SER hierover advies vroeg. De hoofdlijnen voor een eventuele wettelijke regeling voegde de minister erbij. De minister Jiet echter wel duidelijk merken dat hij zich gestuurd voelde. Na gemeld te hebben dat het kabinet gemeend heeft aan het verzoek van de Kamer te moeten voldoen vervolgt hij: "Daarbij zij evenwel voorop gesteld, dat het Kabinet van mening is en blifft dat

40. Dienst Collectieve Arbeidsvoorwarden, Gewetensbezwaren in dienebetrekking. Den Hag ro87; wv-nota, Gewetensbezwaren in de werksituatic, 1982 ; CHV-belcidsnota, Gewetensbegwarev van werknemers, 1983.

41. SER-advics, Gewetensbezwarem in dienstbetrekking, 1990, nr. 10, p. 13 .

42. $7 \mathrm{k}$ - $198,5-1986,19377$, nirs. $1-2$.

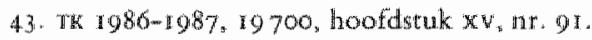


de problematiek van de gewetensbezwaren in dienstbetrekking zich bij uitstek leent voor zelfregulering door sociale partners en dat een wettelijke regeling niet voor de hand ligt:.44

In juni 1990 bracht de ser zijn adwies wit. Het is opvallend - gezien de voorgeschiedenis - dat het cen unaniem advies betreft. Maar dat heeft warschijnlijk ook te maken met het feit dat een mixture is gecomponeerd wan een wettelijke basisnorm in combinatie met een samenstel van gedragsnormen, ontleend aan bestaande arbeidsrechtelijke normen in het $\mathrm{Bw}$. Zoals die met betrekking tot het goed werkgeverschap (art. r638z) en het goede werknemerschap (art. r639d), en die met betrekking tot de loondoorbetalingsverplichting (art. $1638 \mathrm{~b}$ ) en de risicoverdeling (artt. $1638 \mathrm{c}$ en $1638 \mathrm{~d}$ ). De hieruit afgeleide normen zijn fatsoenlijk en voor de hand liggend: beide partijen moeten doen wat in hun vermogen ligt om conflictsituaties te vermijden, zodra er sprake is van gewetensbezwaren moet overlegd worden, vanaf het beroep op de gewetensbezwaren tot op het moment dat conclusies worden getrokken moet het loon worden doorbetaald, passende vervangende arbeid moet worden gezocht, en, is tensllotte beëindiging van de dienstbetrekking onvermijdelijk, dan verdient het aanbeveling om de normale ontslagprocedure te volgen.

De wettelijke basisnorm zou moeten bestaan uit een toevoeging aan het tweede lid van art. $1639 \mathrm{~s} \mathrm{BW}$ dat beeindiging van de dienstbetrekking kenmelijk onredelijk zal kumnen worden geacht, wanneer deze geschiedt wegens het enkele feit dat de arbeider als gevolg van een beroep op een emstig gewetensbezwaar weigert de bedongen arbeid te verrichten. Volgens de SER zal de bepaling uitstralingseffecten hebben op de arbeidsverhouding, het ontslagbeleid van de directeur GAB en op het rechterlijk oordeel in ontslagprocedures war gewetensbezwaren in het geding zijn. Dat hoop en verwacht ik ook. Eveneens is de wettelijke basisnorm in beginsel een gelukkige. Toch valt wel enige kritick te leveren. Zo kan bijvoorbeeld de beperking tot gewetensbezwaren alleen in verband met de bedongen arbeid in de praktijk tot problemen leiden. Vermeulen noemt als voorbeelden een werknemer die zich in geweten verplicht acht op zijn werk bepaalde door zijn levensovertuiging voorgeschreven kleding te dragen, of zich gedwongen woelt de

44. Adviesaanwaag d.d. I aprill 1988 . Opgenomen als bijlage i bij het ser-advies, ta.p. p. 12 . 
ernstige misstanden in zijn organisatie woortdurend in de openbaarheid te brengen. ${ }^{45}$

Zoals de SER van de wettelijke basisnorm een uitstralling verwacht, verwacht hij die ook van de niet-wettelijke gedragsnormen, en wel richting sociale partners. Hierover ben ik minder optimistisch. Ook op dit punt is er geen reden om van het zelfregulerend vermogen van de sociale partners al te veel te verwachten - de unanimiteit in de SER ten spijt. Voorlopig is de leidraad voor ondernemingen over dit onderwerp van de Stichting van de Arbeid niet weel verder gekomen dan een parafrasering van het SER-advies. Wel wordt er nog een advies bijgegeven: als in de onderneming wordt afgezien van een specifieke regeling voor de behandeling van gewetensbezwaren, dan kan altijd nog worden overwogen om klachten van deze aard volgens de algemene klachtenregeling in de onderneming te behandelen.

En het kabinet? Zou nu ook het kabinet, na het unanieme SFR-advies en gezien de psychische druk die niet gehoorde en gehonoreerde gewetensbezwaren met zich mee kan brengen voor werknemers, niet alsnog bereid zijn tot de voorgestelde, toch wel uiterst summiere daad van wetgeving?

In de jongste MvT bij de begroting van het ministerie van Sociale Zaken en Werkgelegenheid heet het ietwat geheimzinnig dat 'een standpuntbepaling met betrekking tot een wettelijke regeling' wordt voorbereid. ${ }^{46}$

\subsection{Seksuele intimidatie in de onderneming}

Seksuele intimidatie - ik sluit me aan bij de opvatting in de recente SER-adviesaanwraag dat deze terminologie, in plats van de term ongewenste intimiteiten, correcter weergeeft war het on gaat-wordt wanaf eind jaren zeventig, begin tachtig als zodanig, als probleem benoemd en in de openbaarheid gebracht. Begin 1981 verzocht de Tweede Kamer om een beleidsnotitie 'waarin tenminste cen verkenning van de problematiek en een informatief gedeelte over de activitei-

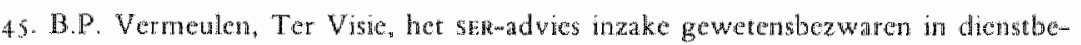
trekking, $\$ R, 1990, p .207$.

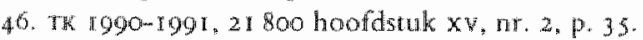


ten van de regering op dit gebied zijn opgenomen". Find 1983 werd door de statssecretaris een woorlopige nota ter advisering aan de SER gezonden. Deze nota wilde de eerste anzet zijn tot een samenhangend beleid ter uitbanning wan seksueel geweld tegen vrouwen en meisjes. Eên paragra f handelde over ongewenste intimiteiten op de werkplek, een vanuit het beleid tot dan toe verwarloosd aspect van werkomstandigheden van buitenshuis werkende vrouwen zoals de notitie zegt. Terecht wordt daarbij onder meer opgemerkt dat dit probleem "vaak een zeer nadelige uitwerking heeft op het functioneren van vrouwen in de arbeidsorganisatie. Onderzoek, voorlichting, studie, vertrouwenspersonen en klachtrecht zijn de in de nota voorgestelde beleidsinstrumenten. Ook zal studie worden verricht om duidelijk te krijgen of en zo ja op welke wijze regelgeving wenselijk is. De sER adviseert, betrekkelijk snel, in het voorjaar van 1984 . De raad meent vooralsnog dat nadere regelgeving niet nodig is en dat in Nederland nog te weinig gebruik wordt gemakt van de al bestaande juridische mogelijkheden. Een beleid gericht op het voorkomen en bestrijden van ongewenste intimiteiten op de werkplek moet onderdeel zijn van het sociale beleid in de onderneming. Het is primair de takk van de ondernemingsleiding om dit beleid vorm te geven en zonodig corrigerend op te treden.

Welke zijn nu eigenlijk die bestaande juridische mogelijkheden waar de SER het over heeft? De sER noemt bepalingen in het Wetboek van Strafrecht, de ontslagbepalingen in het Bw, wetgeving op het gebied van gelijke behandeling en de wor. Ik voeg er nog aan toe de Arbowet, de cao en enkele andere bepalingen in het $\mathrm{B} w$ betreffende verplichtingen van de werkgever.

Het Wetboek van Strafrecht is ten aanzien van situaties in de arbeidssfeer nier, of nauwelijks, namelijk slechts bij zeer ernstige gevallen van seksuele intimidatie, een geschikt instrument. De verplichtingen voor de werkgever in het $1 w$, met name de art. $1638 \mathrm{z}$ en $1638 \mathrm{x}$ (de verplichting van de werkgever om zich als goede werkgever te gedragen en zijn verplichting om te zorgen voor veilige en gezonde arbeidsomstandigheden) zijn in veel gevallen te algemeen geformuleerd, - net als art. 1401 - om recht te doen an de specifieke seksuele intimidatie-

47. TK 1980 -198, 16400 hoofdstuk XVI, nir. 80 .

48. Opgenomen als bjlage bij sep-advies Commentaar ongewerste intimireiten op de werkplek, Den Hang 1984 , nr. 4 . 
gevallen (nog los van bewijsrechtelike problemen), terwijl zij zich in eerste instantie richten op de verhouding werkgever-werknemers. De mogelijkheden van ontslagneming op staande voet door de werknemer (art. $1639 \mathrm{q} \mathrm{lid} \mathrm{2)} \mathrm{of} \mathrm{het} \mathrm{verzoek} \mathrm{om} \mathrm{ontbinding} \mathrm{bij} \mathrm{de} \mathrm{kantonrechter}$ (art. I 639w) vormen geen èchte juridische oplossing voor het probleem van seksuele intimidatie. De mogelijkheid tot het krijgen van een schadeloosstelling in die gevallen is niet veel meer dam een pleister op de wonde. ${ }^{49}$ De Wet gelijke behandeling schiet met name op het terrein van de sanctionering te kort. Van de bepalingen in de wor, het initiatiefrecht (art. 23), het instemmingsrecht (art. 27) en het waken tegen discriminatie (art. 28) moet in de praktijk ook niet al te veel verwacht worden. Al zou dit wellicht anders kunnen zijn indien een speciale vrouwen-commissie (ex art. Is lid I) voor dit doel wordt ingesteld. ${ }^{.0}$ De Arbowet zou een functie kunnen vervullen bij een preventief beleid ten aanzien van seksuele intimidatie op de werkplek. Probleem is echter dat op basis van deze wet het slachtoffer geen directe actiemogelijkheid heeft, de dader in het algemeen niet rechtstreeks kan worden aangesproken en dat de Arbeidsinspectie zich, zeker ten opzichte van dit onderwerp terughoudend zal opstellen omdat het niet onmiddellijk duidelijk is onder welke bepaling seksuelle intimidatie precies gebracht zou moeten worden. Uit caomonderzoek tenslotte is gebleken dat zowel $\mathrm{k}$ wantitatief als kwalitatief bepalingen terzake niet beschouwd kunnen worden als een effectief instrument tegen intimidatie op de werkplek. In 1989 vond men in 22 van de 75 onderzochte cao's een bepaling; deze waren van toepassing op $31,6 \%$ van de werknemers. Inhoudelijk moet geconstateerd worden dat in de cao's onvoldoende aandacht is geschonken an het goede werknemerschap (de dader is ook werknemer), an personen die anders dan op arbeidsovereenkomst zich in de onderneming bevinden en het ophouden van de verantwoordelijkheid van de werkgever bij het reageren op een mal opgetreden seksuele intinidatie. Aan preventie wordt aldus onvoldoende aandacht besteed.

49. Vgl. L. Andringa, In plats van ontag, in: Ongewenste intimiteiten, gewenste rechten, Aphen anden Rijn 199: , p. 102.

50. J. Tichelarar, Het wooded wan de ewifel, in. Ongewerste intimiteiten, gewenste rechem, Alphen an den Rijn 1990. p. 167.

SI. C. Schute, Van incident tot arbeidsrisico, in: Ongewenste intimiteiten, gewenste rechten, Aphen aan den Rijn 1090, p. Is3. 
Conclusic uit het voorafgaande kan geen andere zijn dan dat hoewel met een creatieve interpretatie van de diverse al bestaande regelingen. veel beteikt kan worden, het beter is orn tot een meer samenhangende, sluitende wettelijke regeling te komen. ${ }^{52}$ In haar recente adviesaanvraag van mei van dit jaar aan de Emancipatieraad en de SER meent ook de staatssecretaris dat het huidige wetsinstrumentarium lacunes vertoont. Dat neemt niet weg dat zij, na het opnoemen van mogelijkheden, maar vooral van soms onoverkomelijke moeiljkheden bij de toepassing en eventucel aanpassing van de Arbowet, de Wet gelijke behandeling en het $B W$ tot een terughoudend geformuleerde adviesaanvraag komt. Hierin vraagt zij met name of er mogelijkheden zijn om het huidige juridische instrumentarium beter te benutten, wat gevonden wordt van de geschetste knelpunten, of er suggesties zijn voor andere maatregelen en of er aanleiding is om tot aanvullende wetgeving over te gaan. Het zou de staatssecretaris gesierd hebben als zij in elk geval de laatste vraag positief had beantwoord te samen met een schers - niet ongebruikelijk - hoe zij zich dat had voorgesteld.

\subsection{Deeltijduerkers in de onderneming}

Al in 1975 meende de regering dat deeltijdwerk een belangrijk instrument zou kunnen zijn in de strijd tegen de werkloosheid. Meer aandacht voor het verschijnsel. ware derhalve gewenst. Vervolgens $\mathrm{kwam}$ het onderwerp in politicis en daarbuiten, bijvoorbeeld in $198 \mathrm{I}$ in een FNV-nota, regelmatig ter sprake. ${ }^{53}$ Het ging daarbij in het algemeen over twee zaken: deeltijdarbeid als arbeidsmarktinstrument en rechtspositionele aspecten van deetijdarbeid. Ik zal me hier vooral met het latste bemoeien, en dan nog alleen met de onderwerpen: gelijke behandeling van deeltijd-en voltijdwerkers, het een derde criterium in de Wet minimumloon en vakantiebijslag (WML), het gelijke uurloon en het en derde criterium in de wor. Ik ga dus voorbij an de fiscale, pensioenrechtelijke en sociaal-zekerheidsrechtelijke aspecten.

52. $\mathrm{Y}$. Konyjn, Bij gebrek aan unitome wetgeving, in: Ongewenste intimiteiten, gewonste rechten, Alphen aan den Rijn 1990, p. 21.7.

53. FN\$, Een deel van her geheel, wN-wisie op deelijdarbeid, Uitgangspunten voor cen gefaseed en gericht stimuleringsbeleid. Amsterdam, juli ing $8 x$. 
In 1987 bood de minister van Sociale Zaken en Werkgelegenheid een nitwoerige nota Deelrijdarbeid aan aan de Tweede Kamer. ${ }^{54}$ op dat moment bedroeg de deeltijdarbeid ongeveer een $\mathrm{kwart}$ van de totale werkgelegenheid. Een verdere groei is intussen gerealiseerd-alleen minder dan werwacht. De belangrijke doelstellingen die bij de bevordering van deeltijdwerk een rol spelen zijn - naast de werkloosheidsbestrijding - het kunnen bieden van werk aan personen die alleen beperkt arbeid kunnen of willen verrichten, bijvoorbeeld wegens leeftijd of handicap, en het kunnen leveren wan een bijdrage aan het realiseren van een belangrijke emancipatiedoelstelling, nanelijk het streven naar economische zelfstandigheid van wrouwen - alleen maar succesvol als ook mannen meer evenredig in deeltijd zouden gaan werken. Deelrijdwerk $\mathrm{k}$ an de psychische belasting - leidend tot arbeidsongeschiktheid met name bij vrouwen - die veroorzaakt wordt door de druk van de combinatie betaald werk en huishoudelijke taken verminderen. Maar het is natuurlijk wel zaak om àls geconstateerd wordt dat het voomamelijk vrouwen betreft, zo'n $80 \%$ in vooral de lagere functies, ervoor te zorgen dat in ell.k geval hun rechtspositie geen reden is of om eraan te beginnen ò om er voortijdig mee te stoppen. Helaas is dat nog steeds niet het geval.

Uit de WML volgt dat werknemers, geheel los van de aard van het werk, aanspraak kunnen maken op tenminste het minimumloon. Deeltijdwerkers op een eventedig deel naar rato van het aantal gewerkte urern. Deeltijidwerkers die echter een dienstbetrekking hebben van minder dan een derde van de normale arbeidstijd, kunmen aan deze wet geen aanspraken ontlenen. Dit zogenaamde $1 / 3$-criterium is steeds onderwerp van discussie geweest, al tijdens de parlementaire behandeling van de wML. ${ }^{3 .}$ En tetecht. Er is hier immers sprake van een drempel die een ongelijke behandeling veroorzaakt tussen met name vrouwelijke deeltijdwerkers, althans voor minder dan een derde van de normale tijd, en voltijdwerkers. Ook de regering deelt vanaf eind jaren zeventig regelmatig mee dat zij af wil van het $1 / 3$-criterium in de WML. In de SER bestaat eveneens een meerderheid voor afschaffing. ${ }^{37}$ In de nota van 1987

\footnotetext{
54. TK 1986-1087, 19902, ar. 1-2.

55. Zieherover $O$. Abers, Arbeidsrechtelike aspecten wandecltidarbeid, in: Deeltijdarbeid. Deventer 1983 , p. 60 .

56. M. Bruyn-Hundt, Het $1 / 3$ wcriterium in de Wet minimumloon, $5 M A, 1987$, p. 139.

57. SER-advies Vrijwillige deeltijdarbeid, Den Hag 1985, nr. I1.
} 
Wordt opnieuw uitgesproken dat de minister in beginsel positief staat tegenover afschaffing. Maar, en nu komt het, vooral omdat als gevolg van afschaffing negatieve arbeidsmarkteffecten kumnen optreden wordt gewacht met de afschaffing van het 1/3-criterium. De dominantie van de markt over principiele aspecten van rechtspositionele aard, namelijk van gelijkheid-ongelijkheid, wordt hier wel zeer treffend geillustreerd.

De nota van 1987 werd ook voorgelegd aan de Stichting van de Arbeid. Deze adwiseerde ruim iwee jaar later. ${ }^{58}$ Werknemersleden waren - evenals in de sEn-vóór afschaffing van het $1 / 3$-criterium, werkgeversleden koppelden een eventuele afschaffing aan een forse verlaging van liet minimumloon. Zolang dat niet gebeurt zijn zij tegen. In juli van dit jaar zendt de nieuwe minister opnieuw een notitie over deeltijdarbeid aan de Tweede Kamer. ${ }^{59}$ Daarin wordt eindelijk medegedeeld, rum elf jaar na een dergelijke aankondiging, dat een wetsvoorstel tot afschaffing van het $1 / 3$-criterium in wML zal worden ingediend.

Samenhangend met het hierboven genoemde is er de problematiek van toekenning aan deeltijdwerkers van een evenredig deel van het loon (boven het minimumloon) dat zij zouden verdienen als zij voltijds zouden werken. Een evenredigheidsbepaling ten behoeve van de beloning van deeltijdwerkers ontbreekt in de wetgeving. In de nota van 1987 wordt opgemerkt, mede omdat het een essentiële arbeidsvoorwaarde betreft, dat het overweging verdient om de lacune op te vullen. De Stichting van de Arbeid is verdeeld: de werkgevers, nu gesteund door MHP achten een wettelijke regeling in strijd met de terughoudendbeid die de overheid moet betrachten op het terrein van de arbeidsvoorwaarden. De overige werknemers staan positief ten opzichte van een wettelijke regeling. Terecht. Het gaat immers niet om de hoogte van de beloning mar om gelijke behandeling. Gelet bovendien op het feit dat $80 \%$ van de deeltijdwerkers vrouw is, zou en verschil in behandeling cen indirect onderscheid tussen mannen en vrouwen met zich mee kunnen brengen warvoor onvoldoende rechtvaardigingsgronden kunnen worden angedragen. ${ }^{60}$ Vooral echter in verband met praktische problemen - welke loonbestanddelen kunnen tot het loonbegrip worden gerekend? e.d. - meent het kabinet in zijn nota van 1990

58. Stichting van de Arbeid, Nota Deeltijarbeid, Den Hag, april 1989.

59. TK $1980-1990,2165 \%$, nr. 1 .

60. Zie ook M. Bruyn-Hundt. ta.p. p. I43; TK $1989-1990,2$ r 655, ne. I, p. 5. 
en in afwijking van het voormemen in 1987 nog eens een adviesaanvrag. aan de SER te moeten voorbereiden. Het lijkt mij onverantwoord vooruit- c.q. afschuifwerk. Is er overigens één reden on te veronderstellen dat het standpunt wan werkgevers en van werknemers zich zal wijzigen?

Het is duidelijk uit het voorafgaande dat het uitgangspunt van zowel regering als sociale partners - ik mak dat onderscheid nog steeds - dat 'het niet maken van onderscheid tussen werknemers op de enkele grond dat de ene werknemer zich voor minder uren per periode verbonden heeft arbeid te werrichten dan de ander, tenzij en voor zover daarvoor een rechtvaardigheidsgrond kan worden aangevoerd" voor een gedeelte slechts een papieren uitgangspunt is. ${ }^{61}$

Waarom eigenlijk niet gelijke behandeling van deeltijd- en woltijdwerkers in de wet als algemeen beginsel vastgelegd? Ook hier denken de sociale partners, volgens de bekende scheidslijnen (alleen her cNv heeft zich dit keer bij de werkgevers en MHP gevoegd) verschillend over. Uiteindelijk vindt het kabinet in de notitie van 1990 dat eerst maar onderzoek van de Loontechnische Dienst en de Dienst Collectieve Arbeidsvoorwarden naar de regeling van de rechtspositie van deeltijdwerkers moet worden afgewacht. Moet dat nu echt? Als blijkt dat deeltijdwerkers ten tijde van het onderzoek 'goed' behandeld worden is dan een wettelijke verankering van gelijke behandeling niet meer nodig? Wetgeving wil toch juist een garantie geven, zeker als het om principiële zaken gaat, voor simpel gezegd goede en slechte tijden?

Een laatste aspect betreft de medezeggenschap en het $1 / 3$-criterium. Volgens de wor tellen in ondernemingen met tussen de Io en 35 werknemers werknemers die minder dan een derde van de normale arbeidstijd werken niet mee bij bet bepalen van het aantal werkzame personen en hoeft de ondernemer hen ntet mee te laten doen aan de verplichte gezamenlijke personeelsbijeenkomsten. In ondernemingen met tussen de 35 en 100 werknemers tellen zij evenmin mee en bizitten zij niet het actieve en passieve kiesrecht. Waarom de wetgever voor de $1 / 3$-grens heeft gekozen is onduidelijk, terwijl de toelichting uiterst summier was: de geringe betrokkenheid van deze werknemers bij de onderneming. "Het argument is niet erg steekhoudend: geldt dat dan immers niet voor deeltijd werkers in grote ondernemingen? In middels is

6r. Nota deeltijdarbeid., tá.p. p. 24

62. O. Albers, ta.p.p. 73 . 
onderzoek uitgevoerd naar het functioneren van de medezeggenschap in middelgrote (35-100 werknemers) ondernemingen. ${ }^{63}$ Uit dit onderzoek blijkt dat in zijn algemeenheid niet van een geringe betrokkenheid van de zogenaamde kleine deeltijdwerkers bij de gang van zaken in de onderneming kan worden gesproken. Derhalve vraagt de minister in zijn adviesaanvraag aan de sER van augustus 1989 inzake de wor of het $1 / 3$-criterium in de won voor de middelgrote onderneming zou kunnen vervallen. Ook een eerder onderzoek naar het functioneren van de medezeggenschap in kleine ondememingen (10-35 werknemers) gaf geen aanleiding om daar het $1 / 3$-criterium te handhaven. ${ }^{64}$ Alleen wraagt de minister hierover niets aan de SER in de zojuist genoemde adviesaanvraag, maar stelt hij afschaffing van het $\mathbb{1} / 3$-criterium voor.

Per saldo een gemengd beeld: eindelijk wordt voorgesteld om het 1/3-criterium in de wML in te trekken, maar geen voorstel tot wettelijke regeling van een evenredig deel van het loon of van een algemeen uitgangspunt van gelijke behandeling van deeltijd- en voltijdwerkers. Ten aanzien van de wor wordt ten dele gevraagd naar afschaffing van het $1 / 3$-criterium en wordt het ten dele voorgesteld.

Intussen publiceerde de Europese Commissie op 8 september van dit jaar voorstellen voor communautaire richtijnen inzake deeltijdwerk, overigens ook na een lange voorgeschiedenis. ${ }^{6 s}$ Richtlijn I geeft meer algemene voorschriften, Richtlijn II beoogt harmonisatie van arbeidsvoorwarden, anders dan loon en de derde richtlijn geeft regels ter verbetering van de veiligheid en gezondheid.

Ten aanzien van de nu besproken onderwerpen betekent het aannemen van deze Richtlijnen in elk geval dat de wettelijke $1 / 3$-criteria overal in de wet geschrapt dienen te worden; de mogelijkheid dat de deeltijdwerker niet naar evenredigheid loon krijgt uitbetaald zal juridisch worden uitgesloten. Het is te hopen dat we de internationale regelling vóór kunnen zijn.

63. Tnstitutit wor social-wetenschappelijk onderzock. Medezeggenschap in middegrote ondememingen, Tilburg rogo.

64. Institur voor saciaalmetenschappelijk onderaek, Medezeggenschap in kleme ondernemingen, Tilburg ro 97 .

65. Prublikatieblad ni. C 224/4, 8 september 1990. 


\section{Een balans}

Tussen de redes van Den Uyl en van Lubbers is in ons land duseen aantal arbeidsrechtelijke onderwerpen - ik heb ze niet allemaal genoend - de revue gepasseerd die elk voor zich, sommige direct, andere meer indirect, in de preventieve sfeer een bijdrage hadden kunnen leveren aan de voorkoming van arbeidsongeschiktheid. Toch is dat niet gebeurd. Wat is nu het gemeenschappelijke in die onderwerpen?

In de eerste plaats valt op dat het meestal gaat om de toekenning van individuele werknemersrechten in de sfeer van de (sociale) grondrechtem. ${ }^{\text {is }}$ De toekenning daarvan is nooit van een leien dakje gegaan - en heeft in die zin ook een lange voorgeschiedenis bijvoorbeeld. in het kader van de Grondwet. $\mathbb{k}$ moge hiervoor verwijzen naar de vragen, later gevolgd door een nota van Van der Goes van Naters inzake een algemene catalogus van 'onvervreemdbare grondrechten der menselijke persoonlijkheid' ter gelegenheid van de grondwetsherziening van 1948 . Hierbij noemde hij ook sociale rechten, waaronder volledige psychische, intellectuele en morele ontwikkelingsmogelijkheden, sociale wetgeving, plicht tot arbeid en recht op bestaansmogelijkheden. De regering beperkte zich in eerste instantie tot het uitspreken van haar grote waardering. ${ }^{67}$

Ook bij de behandeling van de herziening die in 1983 leidde tot de opneming van sociale grondrechten in de Grondwet dienden enige PvdA-leden een nota in teneinde in de Grondwet te komen tot de opneming van grondrechten voor individuele werknemers ${ }^{68}$ Aan de werknemer diende de 'positie te worden verschaft van gelijkwaardige deelnemer an het werk van de bedrijfsgemeenschap voor de samenleving. Daarbij zullen dusdanige arbeidsomstandigheden moeten worden geschapen, dat deze deelnemer in zijn werk de mogelijkheid heeft tot maximale zelfontplooiing, zelfrealisatie en verantwoordelijkheid". Hoewel de regering et ook toen weer niet negatief tegenover stond was

66. P.F. van der Hejiden "Grondrechten in de ondermeming, (redc) "Dewenter I988.

67. A.W. Heringa, Socialic Grondrechten, Den Hxag 1989. p. 12.

68. TK $1975-1976,13873$, nes. $5-6$, p. $21-28$. 
yoor cen afgewogen oordeel nadere aralyse, studie en overleg nodig. Verwolgens werd er in dat kader niets meer vemomen. ${ }^{\text {to }}$

Kenneligk valt het niet mee on via de toekenning van indwiduele werknemersechten het door Hekkelman zo kernachtig geformuleerde beginsel te dootbreken: "De positie van de werknemer in de onderneming wordt immers ook nog in belangrijke mate niet door het recht mar door de werking van macht en onmacht bepaald. ${ }^{\text {70 }}$

Het volgende dat opvalt is de-vaak zeer-lange duur van het proces, Na de lancering van het idee, van wie dan ook afkomstig, komt de grote heen-en-weer-schuif-operatie op gang. Van regering naar parlement, naar de Stichring wan de Arbeid, naar de SER, naar een of meerdere van de talloze onderzoeksinstellingen, en weer terug langs dezelfde of weer andere haltes. In het algemeen wordt er in de loop van het traject weing bijgevoegd, maar gater steeds meer af. Als het al tot een regeling komt is zij vaak door het compromiskarakter, dat inherent is an de voorgeschiedenis, geheel of gedeeltelijk uitgekleed. Als het gaat on wetgeving resteert soms slechts symboolwetgeving. Dit wordt bereikt door het ontbreken van concrete normen of hulpregels (klachtrecht), door vage, open formuleringen (welzijnsbeleid), door het hanteren van geralscriteria (verplichting tot het maken van een jaarplan, tot het uitwoeren wan taken op het gebied van het wellyin en de bedrijtsgezondheidszorg), door het uitsluiten van bepaalde groepen zoals deeltijdwerkers, stagiaires, ingeleende werknemers (bijvoorbeeld bij het klachtrecht en gewetensbezwaarden). Soms word het ene onderwerp ook gebruikt als alibi om andere zaken niet of minder te reguleren. Zo wordt in de praktische aanbeveling van de Stichting van de Arbeid inzake gewetensbezwarden verwezen maar het algemeen klachtrecht als in ondememingen geen specifieke regeling zou worden gemaakt. Eenzelfde verwijzing kont voor in de adviesaanvraag van de staarssecretaris over seksuele intimidatie op het werk.

Het meest opvallend in al deze kwesties is echter de rol die de overheid niet speelt, maar wel zou mòeten spelen, namelijk die van hoedster van het algemeen belang en, in her kader van het sociaal recht

69. MuA, tap. p. 14. Een jat later kwam minister Boersma arop terug tidens enen commissicvergadering. Hil dedde toen mee de Kamergrang te infomeren over hat resultate van de verdergande interne studic"; ock, 15 maart $1976, \mathrm{p} .660$.

70. G. Mekkelman, Tekorten wan het arbeidsreht, Amsterdam 1967, in: Arbeidsrehtelike goshriften, 1962-1977 (samenst. H.L. Bakels), Deventer/Alphen aan den Riju 977, p. 92 . 
special die wan beschermster van degenen die in de feitelijke machtsverhoudingen aan het kortste eird trekken. De rol van de overheid als een terugtredende, misschien beter als een wachtende overheid, met natne op het gebied van het sociaal recht, strookt miet net de verbaal en in geschrifte beleden en overigens zeer terechte bekommemis over bet grote aantal arbeidsongeschikten. Ik pleit dus voor een actieve, wetgevende overheid. En dat is aanzienlijk meer dan de activerende overheid zoals die in de jongste MvT $T$ bij de begroting van Sociale Z Zaken en Werkgelegenheid wordt uitgewerkt. Al wordt darin wèl erkend dat het overlaten aan de sociale partners van veel maatschappelijk uiterst belangrijke problemen niet geheel probleemloos is. De bewoordingen zijn omzichtig en omfloerst, maar het lijkt een begin te zijn van op zijn minst een kritisch nadenken over de rol van de overheid in haar relatie met die sociale partners: 'De Nederlandse traditie is er éc van een groot vertrouwen in het zelfregulerend vermogen van de matschappij. Maar toch moet ook geconstateerd worden, dat er vrijblijvendheid kan insluipen in de contacten tussen sociale partners en overheid."

Laat ik er onmiddellijk aan toevoegen dat ook ik wel weet dat wetgeving niet de panacee is voor alle $\mathrm{k}$ wallen. Kwaliteit, effectiviteit, handhaving, legitimiteit en kosten, het zijn evenzoveel problemen die in het kader van - met name recente - wetgeving manifest zijn geworden. ${ }^{32}$ Er zou bovendien nog aan toegevoegd kunnen worden dat beschermende wetgeving, zeker naarmate zij meer gedetailleerd en inhoudelijk is, het bewustzijn kan verdoezelen, dat ook maatschappelijke strijd, als authentiek protestmiddel, van belang is. Maar deze nadelen betekenen dat over oplossingen hiervoor - en in de literatuur is er al veel aandacht aan geschonken - moet worden nagedacht, niet dat vervolgens de Stichting van de Arbeid als plaatsvervangend wetgeefster optreedt. Hoewel de cao, hèt reguleringsinstrument van de sociale partners, ongetwijfeld, afhankelijk van het onderwerp en de omstandigheden, een uitstekend reguleringsmechanisme kan zijn heeft zij ook nadelen. I $\mathrm{k}$ zou in elk geval zeker niet zover willen gaan als Fase die, al doet hij het nog zo voorzichtig. pleit voor een terugtredbeginsel van de overheid in die zin dat een wettelijke regeling eerst van kracht is indien

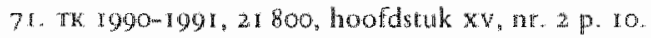

72. Voor een in thet algemeen pessinistisch bodd wan de hadige rechtsvorming in het

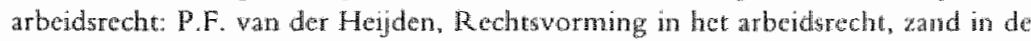
machine, Devatuer 1990. 
de cao geen andere regeling bevat: ${ }^{3}$ Zonder inhoudelijke garanties getuigt dit woorstel van een te groot optimisme in het regulerend vermogen van de sociale partners - zeker wanneer het onderwerpen betreft die ik hiervoor heb beschreven. I $\mathrm{k}$ noem een aantal nadelen van regulering in de cao. In de eerste plats is het afsluiten en de inhoud van de cao in hoge mate afhankelijk van de machtsverhoudingen tussen de partijen. Dit gegeven krijgt nog meer relief in verband met de organisatiegraad in de werknemersorganisaties. Moeizame en langdurige onderhandelingen leiden vak tot voor de werknemers uiterst schrale akkoorden. In de tweede plats kunnen cao-regelingen een ongelijkheid veroorzaken tussen bedrijfstakken en ondernemingen, terwijl daarnaast. niet alle werknemers onder de werking van een cao vallen. In de derde plaats geldt algemeen verbindend verklaring van de cao in beginsel alleen voor de arbeidsvoorwarden, en dus niet voor de meeste onderwerpen die ik hiervoor besproken heb. In de vierde plats dienen dergelijke bepalingen meestal als diagonale normen gekwalificeerd te worden zodat bij schending niet de individuele werknemer, maar alleen cao-partijen naleving kunnen eisen.

Daar komt bij dat het cao-instituut steeds meer onder druk komt te staan onder irvloed van flexibilisering en individualisering. ${ }^{7}$ Ook de internationalisering speelt darbij een rol. En op dat niveau is al helemaal. nauwelijks sprake van een sociale dialoog tussen werkgevers en werknemers, vooral omdat de laatste groep er tot nu toe op geen enkele manier in is geslaagd om een Europese vuist te maken. ${ }^{75}$ Ook al om die reden wordt het hoog tijd dat de èchte wetgever in ons land opstaat. Het zal duidelijk zijn dat ik vind dat dat al veel eerder had moeten gebeuren.

Als op het terrein van de door mij genoemde onderwerpen (en er zijn er nog méér te noemen), alle te maken hebbend met de beschermings-an ontplooingsfunctie van het sociaal recht, in de afgelopen vijftien jaar. deugdelijke wettelijke regelingen tot stand waren gekomen en in werking getreden, dan zou naar mijn mening het aantal arbeidsongeschikten gelet op de oorzaken ervan er anders, positiever witzien.

73. W. P.M. Fase, Collectief arbeidsrecht na viffig jaar, in: Vijeig jaar social recht in Leiden (red. M.G. Rood), Deventer, p. rig.

74. Hierover M.G. Rood, Over de coekomsit van de medezeggensehap, in: Schetsen woor Bakels, Deventer 1987 , p. 229 .

75. Zie bijwoorbeld het vershg wan de eliscussie tijdens de conferentie ower Europa 1992 - Sociale dimensie, in: De sociale dimensie van de Europese integratic, Deventer 1990, p. 73. Zie ook de bijdrage van A.D. Den Broeder hier, ta.p. p. 13. 


\section{De nieuwe oplossingen}

Inmiddels heeft het traditionele najaarsoverleg plaatsgevonden. Sociale partners en overheid hebben in dat kader een uiterst moeizaam bereikt akkoord gesloten over het terugdringen van de arbeidsongeschiktheid. . ${ }^{76}$

Het gaat on twee groepen nuatregelen. In de eerste plaats pleiten de partijen voor een intensivering van het preventieve beleid. Dit zou vooral moeten gebeuren door het maken van afspraken over te nemen maatregelen op het gebied van de registratie, de analyse en het overleg in de onderneming over het arbeidsongeschiktheidsverzuim. Een volgende groep van maatregelen in het kader van het voorgestelde preventieve beleid zou betrekking moeten hebben op een verbetering van de $\mathrm{k}$ waliteit van de arbeid door daarop gerichte plannen voor scholing, vorming, herplaatsing, aanpassing, beperkingen van belastende arbeid e.d. Aparte vermelding verdient hierbij de wens van de drie partners dat op korte termijn afspraken worden gemaakt over de invoering van bedrijfsgezondheidszorg, daar waar dit nog niet het geval is. Er moet een studie komen over de mate waarin en de wijze waarop thans in de openbare middelen en de sociale zekerheidsgelden financiering plaatsvindt in de preventieve sfeer. Onderzocht moet tevens worden of dit voldoende is.

Naast het voorgestelde preventieve beleid pleiten partijen voor een tweede groep maatregelen die betrekking heeft op intensivering van de gevalsbehandeling. De gevalsbehandeling bij ziekte en arbeidsongeschiktheid zou in de toekomst door slechts één uitvoeringsinstantie moeten geschieden.

In een zo vroeg mogelijk stadium moet worden begonnen met activiteiten gericht op herstel en reintegratie. Daartoe wordt een aantal fasen in het eerste jaar van het verzuimproces als interventiepunt aangewezen. Naast de geüntensiveerde aan pak in het Ziektewet-.jaar komt er meer andacht woor de werknemer in de WAO. Ook hier ligt het accent op reintegratie via scholing, arbeidsplaatsen in de luwte e.d. Bovendien wordt gepleit voor aanpassing van de vigerende regelgeving opdat de reintegratie-doelstelling beter tot haar recht komt.

Tot slot is afgesproken om een aantal onderwerpen voor te leggen

76. De volledige tekst wan thet najaarsakkoord staat in Stert. 3 oktober 1990, inr. 192. 
aan adviesorganen, zoals an de sep over het onderzoek ter evaluatie van de WGW.

Wat onmiddellijk opvalt - als men zich tenminste door het gortdroge Hagse mandarijnenproza heeft weten te worstelen - is naast enkele houtsnijdende voorstellen het vooral hanteren van de oude recepten die inmiddels ruimschoots bewezen hebben niet te voldoen: litaniein van goede bedoelingen, nog nader te maken afspraken, adviesaanvragen en nader onderzoek.

Daar komt bij dat een aantal maatregelen niet nieuw is en soms al verplicht. Het voeren van een ondernemingsbeleid gericht op het bevorderen van de kwaliteit van de arbeid is al vanaf I juni 1985 verplicht op basis van art. 4 lid I van de Arbowet. Het maken van een schriftelijk plan daarover vanaf I oktober van dit jaar. Met ingang van diezelfde datum is de werkgever verplicht om rekening te houden met de mogelijkheden van elke individuele werknemer bij de hem op te dragen taken (art. 3 Arbowet). Ik heb de bepalingen hiervoor al genoemd. De verplichting om gehandicapte werknemers in dienst te houden c.g. te nemen bestaat al - niet gesanctioneerd en zonder quoteringsverplichting - sinds de inwerkingtreding van de WAGW in 1986. En al in 1985 heeft de HR bepaald dat de werkgever in moet gaan op het gespecificeerde aanbod van een arbeidsongeschikte werknemer om vervangende passende arbeid te werrichten als hij niet in staat is om zijn gebruikelijke werk te doen. Weigert de werkgever op onredelijke gronden op het aanbod in te gaan dan dient hij bovendien als uiterst effectieve sanctie het loon te betalen dat past bij de aangeboden arbeid."

Gepleit wordt ook voor uitbreiding van de bedrijfsgezondheidszorg, thans alleen verplicht voor bedrijven waarin 500 werknemers of meer werken en wat uitsluitend of in hoofdzaak industriële arbeid wordt verricht. Al in 1986 heeft de Arboraad geadviseerd om het gezondheidsrisico als voornaamste bepalende factor te hanteren voor de urgentie van verdere uitbreiding en verplichtstelling. ${ }^{78}$ De werkgeversleden in de raad meenden echter, we schrijven 1986 , het aantal arbeidsongeschikten was al zeer hoog, dat de wetenschap over gezondheidsrisico's in de bedrijven nog te fragmentarisch is en dat dus nader onderzoek nodig zou zijn, alvorens tot eventuele verdere verplichtstelling over te gaan.

77. HR 8 november 1985 , NI 1986, 309 (van Haaren-CENAVE).

78. Arborad. Advies termijaplanming uitbouw bedrifsgeendheidszorg. Zoetermeer $1986, \mathrm{nr} \times \mathrm{r}$ 
Bovendien zou nader onderzoek moeten uitwijzen in hoeverre wettelijk verplichte bedrijsgezondheidszorg een toegevoegde waarde heeft. In het najarsoverleg zijn de werkgevers op hun wenken bediend: uitbreiding van de bedrijfsgezondheidszorg zal niet geschieden via wettelijke maatregelen, maar via te maken afspraken in de bedrijfstakken. Het lijkt erop dat aan het uitgangspunt dat bedrijsgezondheidszorg voor iedere werknemer beschikbaar moet zijn-ook neergelegd in $E G$ - en $1 A O-n o r m e n-o p$ deze manier nog steeds geen recht wordt gedaan.

En een adviesaanvraag aan de SER - ook trouwens aan de swR en het ABP - over de WAGW kan toch nawelijks meer serieus gepresenteerd. worden in het licht van de evaluatie van de werking van de WAcw waaruit zonneklaar blijkt dat ondernemingen gemiddeld nog geen $2 \%$ van de wAGW-doelgroep aan het werk hebben, terwijl gemiddeld $\$ \%$ de bedoeling was?" Toch meende de statssecretaris onlangs in een interview dat wettelijk verplichte quota door haar niet werden overwogen ondat de werkgevers dat niet wilden. Dat is dus de wereld op zijn kop. Werkgevers staan maar zelden te springen om regels die hun vrijheid zouden kunnen beperken. Maar dat betekent toch niet dat als een groot maatschappelijk belang in het geding is dat de doorslag moet geven? Juist dan moet de overheid inspringen. Natuurlijk zal een verplichte quotering tegen de wil van de ondernemers in de praktijk uiterst moeizaam het beoogde effect hebben. Maar het hoeft ook niet te gaan om een verplichtstelling zonder meer. Er kan een dispensatieregeling aan gekoppeld worden waardoor de werkgever in staat wordt gesteld om aan te tonen dat van hem in redelijkheid niet verwacht mag. worden dat hij an de verplichting voldoet. Dat is te vergelijken met zijn door de ur opgelegde plicht om het aanbod van cen arbeidsongeschik te werknemer om ander passend werk te verrichten te accepteren tenzij hij redelijke gronden kan aanwoeren op grond warvan hij kan weigeren.

Het opnieuw vragen van adviezen over de waw en haar uitvoering toont de overheid op haar slechtst: geen activerende overheid, zelfs geen

79. De volledige evaluatie wan de watw bestat uit then rapporten; wiff worden wiontgegewen door vuga watronder en samenvating, Den Hagr 19yo, wijt door de Sociale Verzekeringsrad, Waaronder en Sanenvattend eindrapport, sve, Zoetermeer 1900.

80. De Werkgever, 23 augustus $4900, \mathrm{p}, 2$. 
wachtende overheid maar een bange overheid. En dat is het laatste waat de arbeidsongeschikten op zitten te wachten.

De heer Lubbers meende dat er net als roo jaar geleden sprake is van een sociale kwestie. Ik kan hem daarin volgen. Maar net als roo jaar gejeden is het uiteindelijk de overheid die via concrete, wetgevende maatregelen het voortouw moet nemen bij de oplossing ervan. Het zou ardig gewcest zijn als de minister-president ook die parallel had getrokken.

Ik heb gezegd en dank u voor uw aandacht. 